\title{
The 1553 Succession Crisis Reconsidered ${ }^{1}$
}

More than any previous dynastic contest, the succession crisis which briefly engulfed England in early July 1553 revolved around texts. Circulating in manuscript and print and communicated viva voce, they included legal and quasi-legal documents, proclamations, sermons, circular letters to local officers, and summonses to prominent individuals. What does such an outpouring of political writing tell us about contemporary understanding of the principles of succession and, more generally, the perceived need to sway public opinion at a time of national emergency?

The Protestant Edward VI needed justification for his bid to avert the succession of his Catholic half-sister Mary and instead advance his evangelical cousin Lady Jane Grey. The new order of succession needed to be put on a stable legal footing and communicated to the ruling elites and the nation at large, whose backing was essential to its acceptance. In confronting Jane, Mary sought to win support for her cause by challenging the legal basis of her rival's title and asserting her own legitimacy. The brevity of the bloodless contest between the two women - it was over in less than a fortnight - has obscured the unprecedented degree to which the protagonists sought to mobilize public opinion that summer. Contemporaries were made to feel they had both a stake and a say in the outcome.

Deliberations about which claim to support took place in institutional fora, from the Privy Council to civic assemblies, borough councils, universities, and colleges, and less formal gatherings. As a result, the mid-century succession crisis momentarily called into being what Peter Lake and Steven Pincus have termed, in a different context, 'an adjudicating public'. ${ }^{1}$ Yet while the phenomenon was short-lived, its

\footnotetext{
${ }^{1}$ I am grateful to Sue Doran, Tom Freeman, Steve Gunn, Dale Hoak, Clive Holmes, Diarmaid MacCulloch, Glyn Parry, Malcolm Smuts, and Arthur Williamson for reading and commenting on earlier drafts of this article; and to Kelsey Jackson Williams for his editorial assistance. The two anonymous readers provided very helpful suggestions for revision.
} 
memory proved of lasting importance to Elizabethan Protestants, many of them veterans of the 1553 crisis.

The crisis was precipitated by the abortive attempt of the dying Edward VI to overturn his father Henry VIII's succession settlement enshrined in the Act of Succession of 1544 (35 Hen. VIII, c. 1) and Henry's last will and testament of $1546 .^{2}$ These stipulated that Mary, Henry's elder daughter, should succeed Edward if he were to die childless; the younger, Elizabeth would take the crown in the event of Mary dying without issue. It has long been recognized that, aside from concern about dynastic purity, Edward's bid to exclude both his half-sisters who had been declared bastards by statute (28 Hen. VIII, c. 7), had been driven by fear that if they married out of the realm, England would fall prey to foreign rule and, still worse, popery; the latter would almost certainly happen anyway upon Mary's accession. The boy king's constitutional improvisations led to a bungled coup on behalf of Lady Jane Grey and a successful counter-coup that swept Mary to the throne. ${ }^{3}$

This essay does not claim to offer a new explanation of the whole debacle. But it does take a fresh look at some aspects of the story which have been neglected in the standard accounts. While most studies, including recent ones by Dale Hoak, Eric Ives, and Anna Whitelock and Diarmaid MacCulloch, concentrate on a few recurring questions - When did Edward decide to alter the succession? Was it his idea or a plot concocted by others? Was the scheme legal? Why did it fail? How to account for Mary's triumph $?^{4}-$ I analyze the constitutional principles behind the new settlement, demonstrate how it was justified to the public, and uncover its Elizabethan legacy.

Rather than focusing on events and personalities, moreover, I deal with political ideas. Traditionally, the scholarship of the subject has confined itself to Edward's 'Devise for the Succession', his letters patent, and Jane's proclamation, mining them for legal minutiae while rarely exploring their language and tropes. By contrast, I examine afresh the sequence of documents setting out the new order of succession and reconstruct the arguments used to promote or dispute it in the public arena. In particular, I analyze the strategies of legitimation invoked by Edward and those who sought to 
implement the king's plan after his death. The dominant tactic, I show, was to emphasize the consent of the majority of the political nation or even, as one privy seal letter put it, 'of the whole state' ${ }^{5}$ Such ubiquitous rhetoric of majoritarianism explains why Elizabethan commentators would later construe Jane's advancement as a form of election.

In weighing up the effectiveness of the propaganda campaign mounted on Jane's behalf, I take issue with several assumptions prevalent in the historiography. Contrary to the influential interpretation advanced by, among others, MacCulloch and Hoak, I argue that, far from embarking on an evangelical mission, the new regime only resorted to religion when Jane's cause began to crumble. Although it is generally accepted that Edward's scheme was illegal, a number of recent scholars nevertheless variously seek to rehabilitate Jane's claim, Ives going so far as to assert that 'right was on the side of Jane Grey' ${ }^{6}$ Ives's is a controversial and, as we shall see, ultimately unpersuasive interpretation of those events as a legitimate bid to install Jane. I further challenge the scholarly consensus which construes Mary's victory as the only successful Tudor rebellion. Such nomenclature does not do justice to the spectrum of contemporary opinion. The historical reality, I suggest, is more complex and should be acknowledged as such.

In conclusion, I turn to the long-term implications of the botched coup. Given that several of the men involved rose to prominence under Elizabeth, it is perhaps surprising that this question has never been posed. Yet, as I show, Sir William Cecil (later Lord Burghley) and Robert Dudley (later Earl of Leicester) drew extensively on their experience of the 1553 fiasco in seeking to prevent the accession of another popish Mary - Mary Queen of Scots.

Overall, this essay provides a new perspective on the significance and context of the 1553 exclusion crisis, in particular debates over and alterations to the succession. By closely reading a series of key texts, it reshapes our understanding of this seminal event in Tudor history.

II. 
Succession law in England had long lacked clarity, and became even more confused by the midsixteenth century. ${ }^{7}$ Few post-Conquest monarchs could boast a secure blood claim, and a number had won the crown by violence. Furthermore, while several previous kings had been deposed on dubious legal grounds, notably Edward II in 1327 and Richard II in 1399, the later fifteenth century had been punctuated by as many as five usurpations, each elaborately justified. Culminating with Henry Earl of Richmond's victory at Bosworth in 1485 and the much-vaunted union of Lancaster and York, these dynastic upheavals had made the legal niceties of succession acutely malleable well before $1553 .{ }^{8}$

The survival of the new royal line which Henry VII inaugurated was jeopardized in the next generation by death and reproductive failure. Henry's elder son Arthur died in 1502 and his successor Henry VIII proved unable to sire a son by his first wife, Katherine of Aragon and later to produce a male sibling for his heir Edward. Henry VIII's matrimonial misadventures and obsessive tampering with the order of succession by statute and will dramatically underscored both the limitations of the hereditary principle and the increasingly arbitrary measures required to compensate for them. ${ }^{9}$ And lurking in the background was the idea that the Tudors ruled by might, not right. Even after Henry VIII had eliminated virtually anyone with a better hereditary claim, Cardinal Pole and Edward Courtenay still remained as challengers in the unlikely event of anyone taking the strict hereditary principle seriously. The 1553 exclusion crisis needs to be seen in the context of this chronic dynastic insecurity and emergent religious divisions. The story of the shambolic bid to alter the succession is quickly told. Edward drafted his 'Devise for the Succession' in late winter or spring of 1553 and, according to Hoak, possibly as early as the spring of 1552 after suffering a bout of measles and smallpox. ${ }^{10}$ With his health failing, the king revised the 'Devise' in late May or early June 1553 at the instigation of his chief adviser and lord president of the Council, John Dudley, Duke of Northumberland. Whereas the previous, more speculative version did not name his successor, Edward now bequeathed the crown to his first cousin Lady Jane Grey, descendant of Henry VII's younger daughter Mary, who on 21 May had married Northumberland's son Guildford Dudley. In mid-June, the king and Northumberland forced the leading 
judges to incorporate the new order of succession into letters patent by assuring them that an act of parliament would be secured to validate the instrument. Lord Chief Justice Montagu claimed that without such an act the attempt to re-organize the succession would be treasonable. The Council and other members of the regime subscribed to the letters patent of 21 June, and soon prepared to summon parliament to give Jane's succession a more solid claim to legitimacy. When Edward died on 6 July, before that could be accomplished, the whole scheme unravelled. Mary, tipped off by someone on the Council about Edward's demise and the imminent plan to capture her, managed to escape, and, gathering supporters en route, proclaimed herself queen at Kenninghall on 9 July, one day before Jane's proclamation in London on the 10th. On the 13th Northumberland led troops toward Norfolk to seize Mary, but with backing for Jane melting away and some of his own colleagues on the Council defecting, he proclaimed Mary in Cambridge on the $20^{\text {th }}$, and was promptly taken prisoner. Upon Mary's stunning triumph, Elizabeth by default regained her position as heir presumptive to her thirty-seven-year-old and still unmarried half-sister.

Before looking closely at Edward's 'Devise', it is important to consider its intellectual origins. In her recent account of early modern princely education, Aysha Pollnitz notes the king's exposure not only to Erasmian but also, from 1551 onward, to Machiavellian influences. Pollnitz then relates his 'Devise' to both currents of thought. ${ }^{11}$ I think we can more specifically trace the inspiration for the 'Devise' to Erasmus's Education of a Christian Prince (1516). Shot through with profound scepticism about hereditary kingship, the treatise insisted that the godly monarch was duty-bound to secure a worthy successor. ${ }^{12}$ Erasmus did not recommend pre-emptive exclusions but, rather, attempted to highlight the necessity of appropriate schooling for the royal heir. Nevertheless, we can easily imagine how this precept would have resonated with Edward, the new Josiah, contemplating the prospect of the popish Mary's succession. Meanwhile, Edward's bold, decisive action in seeking to block it, and pragmatic disregard for the law in the emergency circumstances, bore the unmistakable hallmark of Machiavelli's The Prince (1513). So too did the dubious methods, the 'waies and meanes', which, we 
shall see, he urged his followers to adopt to make his plan stick and so save England's reformation: Machiavellian policy in the service of true religion. What, then, were the constitutional and the broader ideological implications of Edward's plan and how was it justified? More precisely, what are we to make of the language employed to define the principles of succession in the relevant documents, among them the king's own 'Devise' and his letters patent, Jane's and Mary's rival proclamations, and the letters each addressed to their adversaries and potential allies? Jennifer Loach has described Edward's original 'Devise' as 'illogical', Dale Hoak as 'politically incredible' and its provisions as 'bizarre' and 'convoluted'. ${ }^{13}$ This is because the king's intense prejudice against female succession essentially placed the crown 'in abeyance', or consigned it 'to oblivion', until such time as a male heir appeared on the dynastic horizon. ${ }^{14}$ In the earliest draft, which nowhere mentioned Henry’s settlement let alone explained why it was being discarded, Edward designed the order of succession to ensure that after his death the kingdom would be ruled by a Protestant Englishman of impeccable parentage. To this end, he not only omitted both his bastard half-sisters and the foreign-born descendants of Henry VII's elder daughter Margaret who had married James IV of Scotland (the so-called Stewart line), but also stipulated that the heirs of Henry's younger daughter Mary (the so-called Suffolk line), all of whom were female, home-born, and Protestant, should be bypassed in favour of their sons. Realising that none of those as yet unborn sons might be of age when he died, Edward proposed that during a likely royal minority the country should be ruled by the infant king's mother, whom he dubbed alternatively 'gouuernres' and 'regent', with the advice of the Council: a female regency of this sort was a novelty in England, in contrast to France and Scotland. ${ }^{15}$ Were she to die before the young king reached maturity, the realm would be 'gouuerned by the counsel'. Edward's 'Devise' further specified that if there were no male heir at his death, the governess, i.e. the eldest living Suffolk female, would rule jointly with the Council until one was born. ${ }^{16}$ During such a protracted interregnum, everyone would presumably await with bated breath the outcome of the biological race among the Suffolk females to be the first to produce a legitimate son. 
However far-fetched, Edward's was nonetheless an imaginative stab at imposing a degree of control over what John Morrill has aptly called 'dynastic roulette'. ${ }^{17}$ In particular, the notion that in the absence of regal authority executive power could be vested for an indefinite period in a female governor and the Council appears quite ingenious, if also distinctly at odds with the otherwise misogynistic tenor of the 'Devise'. ${ }^{18}$ This might be the first (and so far last) time in English history when a monarch envisaged the country existing without a monarch. Edward's musings reveal the tension between the pull of hereditary succession and a concomitant ambition to neutralize some of its perceived disadvantages even at the price of a temporary suspension of monarchical government. Following Patrick Collinson who, in 1987, coined the term 'monarchical republic' to denote both the mindset of the Elizabethan ruling elites that conceived of the queen's government as bounded by counsel and the diverse opportunities open to contemporaries for participation in local and municipal government, recent scholars have discerned 'monarchical republican' traits both before and after the Elizabethan era. ${ }^{19}$ The temporary constitutional set-up envisioned in Edward's original 'Devise' perhaps comes closest to the essence of the phenomenon as Collinson defined it.

Under the pressure of Edward's rapidly declining health, his subsequent iterations of the 'Devise' in late May-early June 1553 - with the connivance of Northumberland and his men planted in the Privy Chamber - became progressively more opportunistic and arbitrary in their provisions, as well as more voluble in justifying them. For instance, Edward's revamped 'Devise' compromised the principle of male succession by vesting the title in ' $L$ ' Jane and her heires masles' ${ }^{20}$ However, something of the initial intention was salvaged by specifying that the sons of Jane's sisters, Katherine and Mary, and of her cousin, Margaret Clifford, would have precedence over both her own daughters and any other female relative. This condition, however, was soon deleted from a later, expanded version of the 'Devise', no longer extant, that in turn became the basis of the letters patent, which reinstated Jane's sisters (though curiously not her cousin Margaret) in the order of succession. ${ }^{21}$ 
The letters patent elaborated and rationalized Edward's 'limitation of the crown'. Mary and Elizabeth were 'clearly disabled to aske, claime, or challenge the said imperiall crowne' notwithstanding any previous legislation to the contrary. Three reasons of unequal weight were given to exclude them: first, their illegitimacy stemming from the annulments of Henry's marriages respectively to Katherine of Aragon and Anne Boleyn; secondly, their being of the half-blood; and, thirdly, the dangerous prospect that they might contract foreign marriages, 'which would then tende to the utter subversion of the comon-welth of this our realme'. ${ }^{22}$ Of the supposed impediments, only the injunction against bastard inheritance carried force at common law and even that had not stopped Henry VIII's parliaments from accepting his technically illegitimate daughters as potential heirs to the throne. Meanwhile, the grounds given for elevating Jane and her sisters comprised: their near (though not immediate) proximity in blood; their unblemished stock; their English birth; and their honourable upbringing and exercise 'in good and godly learninge, and other noble vertues' (p. 94). ${ }^{23}$ None of these was a recognizable legal principle of succession in England, but cumulatively they strengthened the appeal of Jane, recipient of first-rate Erasmian education, ${ }^{24}$ as heir apparent and of her sisters as fallback candidates. The likelihood that the crown would go to their as-yet-unborn brother, named first in the letters patent, was at this stage functionally nil.

Perhaps the most remarkable feature of Edward's letters patent was its use of the language of merit, in contemporary parlance 'aptness' and 'meetness'. This inevitably raised the question of choice and discretion in determining succession. Undisputed hereditary heirs were routinely credited with possessing qualities desirable in a future monarch; praise was a standard tool of instruction.

Conversely, the emphasis here on the urgency of securing 'such a heade and governer as shalbe apte and meete to rule and governe' (p. 92) suggested that the field was still wide open. Coupled with the ensuing eulogy of Jane (and of her sisters and cousin), this in turn indicated that she (and they) were being preferred precisely on account of their innate worth and promise, which inspired 'greate truste and hope ...that they be and shalbe very well inclined to the advancement and settyng forth of our comon welth' 
(p. 94). Ultimately, rather than having the best hereditary title, Jane emerged as the best candidate chosen by the king. We may surmise that statutory provisions allowing Henry VIII to will the crown had opened up this kind of choice on the basis of his judgment of candidates' respective merits.

A central plank in the proposed re-assignment of the succession was to be a new act of parliament. Despite having been 'lymmited by authorite of parleament', Henry VIII's ruling in favour of his bastard daughters was as good as declared invalid (p. 93). Instead the document called for both parliamentary and extra-parliamentary measures that would help transform Edward's vision into reality. His executors were duly charged:

to see this our said declaracion and lymetacion ... established, ratefyed, and confirmed, as well by authoritye of parleamente as by all waies and meanes as they can... and to represse, reforme, repeale, and make voyde all actes of parlement and all other thinges that shall seeme or be in any wise to the contrary, lett, or disturbance of theis our pleasure and appointement. (p. 98)

In short, the challenge before them was not just to make Edward's limitation of succession legal, but also to figure out how to implement it.

Neither the 'Devise' nor the letters patent expressly mentioned religion, even though Edward's resolve to safeguard the reformation was generally understood to be the driving force behind both. ${ }^{25}$ Henry VIII's legislative experiments had been fuelled by the king's fixation with securing the throne for his descendants and, should his line fail, preventing or at least delaying the advent of the Stewarts. In sharp contrast, Edward's scheme was born of confessional concerns which eventually overrode even his deep-seated aversion to female rule. With the consent of parliament, Henry, whose idiosyncratic religious policy following the break with Rome had satisfied neither the conservatives nor the evangelicals, had trampled over the common law of England, and inserted his previously bastardized daughters into the order of succession by statute. In his last will and testament, the king could have 
nominated virtually anyone he wished to follow his sole legitimate heir. In the event, he merely restated the provisions of his Third Succession Act and his now-lost 1544 will, adding that if his children had no legitimate issue, the crown should devolve to the descendants of his younger sister Mary; even here, however, Henry was inconsistent, for the will inexplicably bypassed Mary's daughter Frances in favour of her own offspring. ${ }^{26}$ Henry's advancement of the Suffolk line at the expense of the Stewarts would ignite bitter contention in the 1560 s and beyond. ${ }^{27}$

Henry had placed some restrictions on the succession of Mary and Elizabeth, specifying that in order to remain eligible they could only marry with permission of the majority of the Privy Councillors. ${ }^{28}$ But despite not wanting the break with Rome and the royal supremacy overturned, he had not explicitly prohibited his heirs from changing his religious settlement. ${ }^{29}$ Edward, by contrast, did his utmost to secure an evangelical successor; and, in the terms of his last will, sternly if unrealistically commanded that the executors must 'nott suffer any peece of religion to be altred' ${ }^{30}$ The boy king rightly dreaded that the Catholic Mary would wreck his religious reforms and return England to the papal fold, and he firmly rejected the proposal floated by some that Mary should be offered the crown in return for a promise not to change religion. And although his decision to debar the Protestant Elizabeth had seemingly more to do with legitimism and national honour than with religion, he probably shuddered in disgust at the prospect of the bastard daughter of the beheaded traitress and adulteress taking the auspicious title of supreme head of the church. ${ }^{31}$ Besides, it would be difficult to exclude Mary and not Elizabeth, unless one recognized the marriage to Anne Boleyn as legitimate. If one did not, then both Mary and Elizabeth were bastards and there was no reason for favouring the younger over the elder except on grounds of religion - and that was not yet recognized as legal. Hence the king's choice of the impeccably legitimate Jane, like him a disciple of the radical Zurich reformers, who, he trusted, would protect and nourish the newly reformed Church. ${ }^{32}$

III. 
Had it taken effect, the exclusion of Mary and Elizabeth would have spelled the end of Henry VIII's line. As modern scholars have long remarked, the plan to install Jane was illegal. ${ }^{33}$ Mary was the next in blood as well as being recognized as heir by Henrician statute and will. Jane was fairly distant in dynastic terms; not only Henry's daughters but also Mary Queen of Scots, Margaret Douglas and her young son Henry Lord Darnley, and Jane's own mother Frances Brandon, Duchess of Suffolk had dynastic priority. Eric Ives is therefore mistaken when he says that Edward was simply 'restoring the legitimate line of inheritance' and common law principles. ${ }^{34}$ Legitimate according to what criteria? Even granted that Henry's daughters were disqualified by their illegitimacy and the Scottish Stewarts by their alien birth - the latter a debatable proposition, in order to effect any such restoration Edward should have advanced not Jane but Margaret Douglas, the eldest home-born Stewart or, at the very least, Jane's mother Frances. ${ }^{35}$ In this respect, Edward's initial 'Devise', which confined the succession to males only and placed Frances's putative son before any other male child of the Suffolk line, displayed signally more coherence, even though it too omitted Darnley.

In any case, for all that he hankered to emulate his father's use of the royal prerogative Edward did not have the right to alter Henry's legislation and will by his letters patent. The exclusion scheme thus flouted both common law and statute, and those carrying out the king's commands, whether now or after his death, would be liable for treason under the terms of the 1544 Act. ${ }^{36}$ That is why the country's chief lawyers entrusted with preparing the letters patent initially refused to cooperate, only capitulating under duress and on condition of receiving an advance royal pardon and a subsequent legislative affirmation of the change, and also why the king angled to have the new settlement approved by parliament, which was set to open on 18 September. Had he lived to see that done, England's - and Britain's - history might have looked very different.

What about the unspecified extra-parliamentary measures to which the letters patent alluded? Edward and Northumberland sought consensus by procuring the assent of the political establishment to 
the new order of succession, though they were manifestly determined to enforce it by violence if necessary. How though to bring the nobility and senior civil and ecclesiastical officers on side and prevent any backsliding? Bullying might work short-term, as with the lawyers; bribes would obviously come in handy; a few individuals might be won over with more exalted promises, as was Archbishop Cranmer when Northumberland assured him that under the new monarch he would spearhead further religious reforms, and that the distinguished Continental reformer Philip Melanchthon would be offered the Regius Chair of Divinity in Cambridge. ${ }^{37}$ For Cranmer as for many others, the deciding factor was Edward's fervent commitment to altering the succession in Jane's favour; and quite a number were swayed by their own reformed beliefs, or the hope of personal advantage, or both. Whatever their motives, they might change their minds once the king died. To compel them to keep their faith Northumberland came up with a formal instrument that required both a signature and an oath.

The 'Engagement of the Council and others to maintain the Succession as limited by the King' was administered on 15 June, as soon as the lawyers had succumbed to Edward's and Northumberland's blandishments and agreed to draw up the letters patent. The text of the 'Engagement', to which 24 Councillors and judges subscribed, made plain that subscription was 'by his majesties speciall and absolute commawndment'; each signatory was practically blackmailed into upholding the new disposition of the crown under the threat of reprisals from the others, in a manner that anticipates the Elizabethan Bond of Association. ${ }^{38}$ On 21 June signatures were again required, this time to endorse the letters patent, and soon totalled $101 .{ }^{39}$ While those who subscribed ipso facto accepted the king's right to nominate Jane, the exercise underscored that consent of the political nation was deemed indispensable to the scheme's success. Apart from trying to ensure that the signatories would not flinch when push came to shove, such devices had a significant propaganda value in themselves, for they could be invoked to convince the wider public at home, and also foreign observers, that the country's political elites were firmly united behind Jane. For the moment, all these documents were supposed to remain confidential so as not to alarm Mary and her potential allies, though inevitably given the number of those in the know, 
the secret was leaked. Mary was also immediately advertised of Edward's death, enabling her to escape and muster support for her cause. If she had fled too early, merely on news of the planned diversion of the succession, she could more easily have been arrested and charged with treason against a living Edward, so the timing of her flight into East Anglia was vital.

IV.

Following Edward's death on $6^{\text {th }}$ July, a halting publicity campaign was launched to persuade the nation of the rightfulness of Jane's claim and in particular to secure the allegiance of London and of local power-brokers. It is instructive to compare the arguments used now with those put forward in the recent letters patent. On $8^{\text {th }}$ July, the Lord Mayor, six aldermen, and several leading merchants had been summoned by the Council to Greenwich, told of the king's demise, and made to swear to uphold the order of succession embodied in his letters patent while keeping it secret for the time being. ${ }^{40}$

The new regime's first public statement, received coldly in the capital, was the proclamation of Jane as queen on 10 July, printed copies of which were available the next day. ${ }^{41}$ While in the main reciting the provisions of the letters patent, the proclamation pressed an overt Protestant agenda that they had conspicuously lacked. Declared supreme head of the church, the new queen solemnly vowed to 'preserue and maintaine Gods most holy word, christian policy, and the good laws, customes, and liberties of these our realms \& dominions'; meanwhile, a putative marriage of either of Edward's allegedly illegitimate sisters to a foreign potentate was terrifyingly unmasked as but the first step towards surrendering 'this noble free realme, into the tirannie and seruitude of the Bishoppe of Rome'. ${ }^{42}$ Englishmen were presented with a stark choice between reformed religion and popery, freedom and subjection.

Furthermore, the proclamation went out of its way to emphasize that Jane claimed the crown by the authority of Edward's letters patent, which had been approved by 'the most parte of his nobles, his 
counsailours, Judges, and diuerse others graue, and sage personages for the profite and suretie of the whole realme'. This conjured up the image of the king together with the majority of the political nation making a joint decision about the succession that they believed would serve the public good. Asserting Jane's 'actuall, and royall possession', the proclamation effectively came clean about the expediency of excluding the heirs appointed by statute, whatever the legal grounds of the case. And since those grounds were distinctly shaky, it went beyond the letters patent and, in addition to the common law rule against bastard inheritance, cited the succession statute of 1536 (28 Hen. VIII, c. 7) bluntly confirming both Henry's daughters as illegitimate. ${ }^{43}$

The circular letters to lieutenants of counties sent on behalf of the new queen further exploited the notion that the majority of the governing elite had consented to Edward's nomination of Jane. The heavily revised copy extant in Northumberland's hand, dating from around 10 July, vividly illustrates the problem of expressing this point without forgoing altogether the argument for the constitutional legitimacy of Jane's accession. Jostling for precedence in the draft were several near incompatible perspectives, as Northumberland struggled to decide whether to emphasize the patriotic motive behind Edward's 'ordenances'; the legal status of the king's 'last will' (a term he used instead of letters patent probably to elicit a parallel with Henry's will, which, however had had the authority of statute behind it); the force of several other 'instrumentes' likewise signed by the royal hand and authenticated by the great seal of England (among them the revised 'Devise' and the 'Engagement'); the endorsement of the king's limitation of succession by most of the nobility, Council, judges, City authorities, and other officers; Jane's de facto possession of the throne; or divine providence. All these were variously marshalled to induce the recipients to pledge their allegiance to Jane and 'resyste the fayned and (untrue) clayme of the lady Mary. Basterd doughter to . . . Henry the eight of famous memory'. Tellingly, Northumberland dithered between 'our just title', 'our just title and possesyon', and 'our rightfull posessyon'. ${ }^{44}$ Far removed from both the clinical neatness of Edward's original 'Devise' and the relative aloofness of his letters patent, this cacophonous display sounded more like partisan polemic than a routine circular. 
Aware that the contents would be relayed to a substantial number of people, Northumberland used virtually every available argument, but stopped short of framing Jane's succession in confessional terms.

Aside from the confused attempts at harnessing the resources of print and manuscript to shore up the new regime, a badly overdue decision was taken to tune the pulpits. Ten days after Edward's death and almost a week after Jane's proclamation, her accession was finally hailed, and Mary's and Elizabeth's illegitimacy trumpeted, by leading Protestant divines - Nicholas Ridley, bishop of London and Edwin Sandys, vice-chancellor of the University of Cambridge. Preaching on 16 July at Paul's Cross, Ridley declared 'the Lady Mary and the Lady Elizabeth...to be illegitimate and not lawfully begotten in the estate of true matrimony accordinge to Gods lawe. And so found both by the clargie and actes of Parliament made in this realme in Kinge Henry the VIII's dayes their father'. Taking his cue from Jane's proclamation, Ridley invoked both canon law and Henry VIII's Second Succession Act and ignored the Third which had superseded it - to buttress Edward's late innovation. According to the herald Charles Wriothesley, Ridley's sermon was greeted with murmuring by the disgruntled congregation. ${ }^{45}$ On the same day Northumberland commanded Sandys to preach at the University Church of Great St Mary's in Cambridge. Enjoining obedience to Queen Jane, Sandys's sermon lambasted anyone assisting Mary as both a traitorous rebel against legitimate authority and an enemy of God. Sandys applied his text, Joshua I: 16-18, to draw a parallel between Jane and Joshua, who succeeded Moses as leader of the Israelites. Apparently, Sandys was on the verge of sending his sermon to the printer, again on Northumberland's orders, when news arrived that Mary had been proclaimed in London. ${ }^{46}$ Had Jane remained on the throne a bit longer, these sermons by Ridley and Sandys would almost certainly have been published. It is revealing, however, that we do not hear of any local ministers taking the initiative to preach the same line. Indeed, the evangelical bishop John Hooper instead rallied support for Mary, whom he considered the true heir: 'yet when she was at the worste, I rode my selfe frome place too place (as it is well knowen) to wyn and stay the people for her party. And wher as an other was proclaymed, I preferred her not wythstandynge the proclamations. ${ }^{47}$ Hooper was not the only 
Protestant seeking to boost support for Mary: one Gilbert Potter publicly asserted the rightfulness of Mary's claim in response to her rival's proclamation in London, and had his ears cropped, becoming the only man punished during Jane's brief reign. ${ }^{48}$

Overall, the propaganda campaign mounted by the Council seems belated and signally lacking in coordination and energy: there is a whiff of a missed opportunity to exploit the new regime's strong reformist credentials or at least prevent detrimental initiatives such as Hooper's. It is true that events moved far more quickly than anybody could have anticipated, and that the speed with which Jane's cause collapsed is almost unprecedented in English history. It is also true that using print would have been time-consuming and neither as effective nor as far-reaching as preaching. Still, there is no evidence that during the brief interregnum, between $6^{\text {th }}$ and $10^{\text {th }} \mathrm{July,} \mathrm{the} \mathrm{Council} \mathrm{had} \mathrm{contemplated} \mathrm{encouraging}$ divines to celebrate Jane's accession in their sermons or that any minister did so spontaneously after she had been proclaimed. 'Northumberland', it has been argued, 'sought to turn the succession crisis into a Protestant crusade against Catholicism, ${ }^{49}$ but that had not been the case at the outset, presumably for fear the issue would prove too divisive. Only when the situation had turned dire and Mary's intransigence and formidable military clout made armed response critical to the regime's survival, did the Council change tack, raise the spectre of a popish reaction in their letters to provincial officers, and commission a couple of sermons. This delay has not been appreciated in the historiography, which characteristically assumes that Jane's accession had been consistently promoted in confessional terms.

The earliest conciliar letters describing Mary as a threat to established religion post-dated Northumberland's departure from London on 13 July. In the letter of the 14th to the sheriff and justices of the peace of Nottingham and Derbyshire, the Council not only repeatedly emphasized Mary's bastardy, but also denounced her for inciting 'the commen pepulle ...to rebellion' and seeking 'meanes to bryng in great sortes of papystes Spanyards and other straungers ...to the greate peryll and daunger of the utter subversion of God's holy worde and of the woll state of this realme'. Meanwhile, loyalty to Jane was presented as a sine qua non of the 'preservation of the trew rellegion and awntiant libertye of 
yor naturell contrey ageanst forren powers' ${ }^{50}$ The message fired off on the $15^{\text {th }}$ to the sheriff and magistrates of Wiltshire again harped on the bastard Mary's seditious courses, though here she was said to be stirring up not the lower orders but 'sundry of the nobles, gentlemen, and others'. Stressing that Jane had been made queen 'by the full consent and agreement of the whole state', the Councillors rehearsed at length Edward's admirable resolve to block Mary's accession, which, the king foresaw, would be 'a mean to the bringing in of strangers, whereof was like to have followed the bondage of this realm, the old servitude of the antichrist of Rome, the subversion of the new preaching of God's word, and of the antient laws, usages, and liberties' ${ }^{51}$ In like vein, the letter directed to sheriffs, justices of the peace, and gentlemen of Surrey on 16 July insisted that Jane's succession preserved 'the Crown in the whole undefiled English blood' and out of the hands 'of strangers and papists'. ${ }^{52}$ By then, however, it was too little too late. Whether the Council's failure to mobilize the Protestants in defence of Jane had averted religious war or ultimately cost them victory is impossible to tell.

Compared to the lengthy and tortuous justifications of Jane's title, the London proclamation of Mary on 19 July was a model of concision. Prepared by the turncoat Councillors and printed forthwith, it eschewed legal minutiae and merely announced that, with Edward dead, the crown was 'most rightfully and lawfully' hers ${ }^{53}$ Mary was duly declared the supreme head of the church, no doubt to anticipate possible procedural objections to her sovereignty in the event of the title's omission, and also to keep Protestants on side until her rule was safely established. And yet only days earlier the same men - the earls of Bedford, Arundel, Shrewsbury, and Pembroke, Sir Thomas Cheyney and Sir John Mason - had accused Mary of deliberately shunning the royal supremacy, a plain indication of her intention 'to bring in again the miserable servitude of the Bishop of Rome, to the offence of Almighty God’. ${ }^{54}$

It made perfect sense for those eager to jump on the Marian bandwagon to suppress any reference to the legal instruments that they themselves had only recently declared invalid. ${ }^{55}$ At first, anyway, no one seems to have paid attention to the precise wording of the proclamation which had been drowned out by universal rejoicing: as the announcement was about to be made at the Cross in 
Cheapside, with the Lord Mayor and the Councillors who had switched allegiance to Mary in attendance, 'there was such shoute of the people with castinge up of cappes and cryinge, God saue Quene Mary, that the style of the proclamation could not be hard, the people were so ioyfull, both man, woman, and childe'. ${ }^{56}$

Contrary to the studied vagueness of the proclamation issued by her quondam opponents, Mary herself had initially asserted her right according to the terms of her father's last succession statute and will. ${ }^{57}$ That was the tenor of what she had said to her entourage when proclaiming herself queen in Kenninghall on 9 July, and of the letters she had dispatched on the same day to the defunct Edwardian Council, to Sir Edward Hastings, and to many others. ${ }^{58}$ However, by 18 July when the momentum behind her accession appeared unstoppable, she issued a proclamation firmly asserting her hereditary credentials (and keeping mum about statute and will), a powerful sign of how she herself conceived of her title: 'By the Queen. Know ye all good people that the most excellent princess Mary, elder daughter of King Henry VIII and sister to King Edward VI, your late sovereign lord, is now by the grace of God Queen of England, France and Ireland, defender of the faith and very true owner of the crown and government of the realm of England and Ireland'. This supremely self-confident pronouncement even set the price on Northumberland's head. ${ }^{59}$

V.

How, then, should we interpret Mary's triumph and what did it portend for Elizabeth? The events of June-July 1553 demonstrated vividly that the sisters' political fortunes were inextricably linked: the two would sink or swim together. Certainly, contemporary exclusionists saw no difference between them. Edward apparently did not believe that the reformation could be saved if he sidelined the Catholic Mary in favour of the Protestant Elizabeth, and evidently no one suggested such a course to him. Nor, for that matter, did anyone oppose the exclusion - for that is effectively what it was - of Frances Brandon, 
whose accession, unlike her daughter's, would at least have preserved a modicum of dynastic propriety. Equally unremarked went the exclusion of the entire Stewart line, which like that of Frances had been first proposed in Henry VIII's will. Only the ambassadors of the Holy Roman Emperor Charles V tried to make diplomatic capital by stoking fears that the French, with whom Charles was at war, would one day seek to uphold the title of Mary Queen of Scots, who was betrothed to the Dauphin. The Imperialists insinuated to Jane's Council that any assistance which Henry II of France might be willing to offer the new regime would be to further the interest of the Scottish Mary. ${ }^{60}$ Meanwhile, the English envoys to the Imperial court in Brussels were given to understand that their hosts expected Jane's husband Guildford to hold the reins of power, and a similar point was made by the French ambassador in London who spoke of Guildford as 'the new King'; ironically, Jane had rebuffed Guildford's request to be styled king, and only made him Duke of Clarence. ${ }^{61}$

It is not hard to divine why there was no attempt at home to promote Mary Queen of Scots, the most obvious dynastic alternative to Mary Tudor: she was a foreign papist. Revealingly, even the French king, at whose court she resided, was ready to assist Northumberland's machinations in order to secure England's backing in his conflict with the Habsburgs for all that Jane's succession would have extinguished the dynastic hopes of his prospective daughter-in-law; perhaps, as the Imperialists suggested, he meant to cause troubles further down the road. ${ }^{62}$ If it were conceded that neither a bastard such as Mary and Elizabeth Tudor nor an alien such as Mary Queen of Scots could inherit the English crown, the next in line should have been Margaret Douglas, Countess of Lennox, who was Henry VII's granddaughter from a junior, naturalized Stewart branch. Yet, because of the family's Catholicism, she was similarly bypassed, as was her seven-year-old son Henry Lord Darnley.

So, although the actual contest that summer was between Jane and Mary, the exclusion crisis potentially affected more individuals (and families) than just Mary and Elizabeth. And this is important to remember, for some of those claims would come to the fore later in the century. ${ }^{63}$ Nor did the confrontation between Jane and Mary translate neatly into a conflict between common law and statute or 
between the new and the Old religion, even if religion was fitfully invoked by the increasingly desperate and divided Council and sedulously downplayed by Mary. Mary's military action is commonly seen as, in Diarmaid MacCulloch's resonant phrase, 'a rebellion by an outsider...against the established Queen Jane'. '[T]hat is how both foreign observers and astute English politicians experienced events', argues MacCulloch, 'and only Mary's zealots correctly anticipated the outcome. ${ }^{64}$ Was Elizabeth a Marian zealot? She and many others, not necessarily enamoured of Mary, surely saw Jane as nothing but a usurper, and her installation as the outcome of a nefarious plot, even if they realized that ousting her puppet regime might not be possible. Rather than inferring from hindsight the 'proper' contemporary view of what transpired and judging those who held it as 'astute' and those who did not as blind and stupid, it makes more sense to distinguish between the perceived validity of Jane's cause and her $d e$ facto position, and then ask what lessons could be drawn from the collapse of Jane's regime both at the time and afterwards.

If there is one thing the 1553 crisis made crystal clear, it was the extreme fragility and malleability of the proprieties of succession in England. Henry's tampering with the law furnished a precedent for his son. Edward's own solution to the problem in turn highlighted the element of choice and expedience in the face of an unwanted successor, as well as nominally giving a say in the matter to the political nation. Yet, unlike both the notables who only weeks earlier had been effectively coerced into signing up to Edward's scheme and the City fathers who, on 8-9 July dutifully pledged support for it, local officials now confronting the rival demands for allegiance from Jane, 'a quene of a new and pretie Invencion' as she was dubbed by Sir Thomas Wyatt and his Sussex neighbours, ${ }^{65}$ and Mary, for so long recognized as the official heir, were actually in a position to make a somewhat more independent and informed decision even if their choices were necessarily determined by a prudential assessment of the likely military outcome of the contest between the rival queens. In numerous cases, this entailed protracted debate in borough assemblies and less formal gatherings as well as consultation with nearby towns and corporations. ${ }^{66}$ In other words, provincial leaders and communities were mobilized in a quite 
unprecedented way, and, though we have no record of how the discussions unfolded, the very fact that they took place, often within established institutional structures, is surely significant: here were politically active citizens practically 'voting' on their future queen.

Although nobody articulated the idea that the active citizen had the right to choose the best monarch, the cumulative effect of the various conciliar communications harping on the majority's alleged consent to Jane's succession fostered precisely such an impression. However fleeting, the experience of deliberation and decision-making in turn powerfully strengthened it.

Contemporaries sensed that something new was afoot. A garbled report which reached a Spanish official in Bilbao via a ship that had briefly docked at Falmouth in mid-July, and which he in turn relayed to Madrid, vividly conveys the turmoil that had gripped England in the wake of King Edward's alleged poisoning and the ensuing face-off between 'the lawful Queen of the land, the daughter of Queen Catherine' and 'a daughter of some duke or lord of England'. Most telling of all, the sailors also maintained 'that summons had been issued in the whole kingdom, in Wales, Cornwall (which is the land near Falmouth), Plymouth and the country round Exeter, that within twenty days two men should be sent from each parish to a general Parliament (ayuntamiento), which was to meet in London to elect a Queen' ${ }^{67}$ The appearance in the dispatch of the word 'ayuntamiento' denoting a municipal council or governing body of a town or city underscores that the dramatic events of the preceding couple of weeks had produced a popular perception, however skewed and short-lived, that representatives of the whole country would have a voice in determining the succession.

Of course the rumours of calling parliament to settle the succession could have been related to the real plans to call parliament to settle the succession, which Edward's death aborted. We may also question how precisely the Spanish sailors meant parish - there were so many parliamentary boroughs in the south-west, fourteen in Cornwall alone, that it must have seemed like every small town would be sending two burgesses. But there is no denying that, with many people actively involved in the contest and still more compelled to declare their allegiance often through institutional channels, public opinion 
on the succession was seen to matter, perhaps to a greater extent than ever before. On 2 August, the eve of Mary's triumphant entry into the capital, the Imperial ambassadors reported that 'In several places in this kingdom placards have been posted up with the inscription: Vox populi vox dei' ${ }^{68}$ The hoary adage spoke with uncommon urgency.

Indeed, several freshly-minted Marian Councillors, including Lord Chancellor Stephen Gardiner, were sufficiently concerned about the unsettling impact of recent events to contemplate the unheard of expedient of calling parliament before the coronation. This highly irregular assembly would, inter alia, 'declare the late King Edward's testament [i.e. letters patent] null and void' and 'discover the intentions of the estates in general and the tendencies of individuals'. ${ }^{69}$ The proposal was eventually rejected and the coronation went ahead without delay, but the episode reveals the seriousness with which the government regarded the late threat to constitutional order, and the concomitant mobilization of public opinion.Mary's victory is often taken to mean that statutory regulations were being accorded precedence over common law. Such a reading, though, is only possible ex post facto. First, it was not at all clear that common law principles straightforwardly applied to the inheritance of the crown. ${ }^{70}$ Besides, how can we be certain that her Catholic allies did not see Mary as the rightful hereditary queen even if in soliciting their aid she herself cited statute and will? After all, Henry's annulment of the Aragon marriage had been disallowed by the pope, and many of the Old religion, including Mary herself, rejected both the invalid annulment and its corollary, her alleged bastardy.

The outcome of the 1553 succession crisis ultimately depended less on what people believed was right or lawful but, rather, on accident and contingency. Had Edward lived long enough to secure a parliamentary warrant for his letters patent and impose a corresponding Oath of Succession, or had Northumberland and the Council managed to gain custody of Mary and more effectively coordinated the military and public relations side of the coup, or had Mary shown less stamina, Jane might have held on to the throne. She and her allies would have probably sought parliamentary recognition of her title, just like her great-grandfather and founder of the Tudor dynasty Henry VII had done half a century earlier, 
his no less tenuous claim recognized shortly after Bosworth by his first parliament. ${ }^{71}$ In the end, it does not seem terribly productive to ask whether Mary had won the crown as the lineal successor of Henry VIII or as his nominee according to the terms of his 1544 Succession Act and will or because she was a Catholic or in despite of it, for different people made different assumptions, often prompted by personal or local allegiance, self-interest, and kinship ties, and, in any case, might be loath to acknowledge the true motive, except in private. ${ }^{72}$ That Mary herself put out competing definitions of her claim within days of each other neatly illustrates the pitfalls of speaking about legitimist sentiment, for what did legitimism signify in these circumstances?

So we are left with retrospective constructions and justifications inevitably coloured by subsequent developments. The fact remains that Mary's accession was greeted enthusiastically by all and sundry. That a nominally Protestant country so welcomed the Catholic queen says a good deal about the contingent cross-cutting of faith, legal sensibilities, and dynastic loyalties. In this instance, respect for the line of King Henry VIII and a long-standing settlement appears to have trumped misgivings about Mary's religion, even though it was the Catholics who had provided the initial impetus behind her bid. ${ }^{73}$ How different might the outcome have been had an effective publicity campaign confessionalized the conflict in advance?

Following Mary's bloodless victory, jubilant Catholic publicists hailed her accession as providential in a flurry of sermons, ballads, poems, and pamphlets. ${ }^{74}$ Decrying Northumberland as the architect of the treasonable conspiracy to install Jane, they portrayed King Edward as a victim and a dupe of his evil counsellor. ${ }^{75}$ Protestants likewise acknowledged the validity of Mary's claim - one psalmist even lauded her as 'the true enheritoure...by her byrth, descending from / Her godly father straight' - while intimating that their continued allegiance depended on the queen's future ecclesiastical policy. ${ }^{76}$ And they violently denigrated Northumberland, who recanted his faith on the scaffold in the vain hope of obtaining a pardon. The duke's shameful apostasy was in turn gloatingly exploited by the Marian propaganda machine. ${ }^{77}$ 
For Elizabeth, the events of 1553 must have been doubly unsettling. Having been confident of her place in the order of succession since the age of eleven, she saw it virtually snatched away and her name dragged through the mud. Most galling of all must have been the conduct of Edward and the leading clerical lights of his establishment, notably Cranmer, Ridley, and Sandys. Reformers, seemingly her natural allies, had betrayed her with an ease which showed all too clearly that they would be prepared to do so again and plump for a more congenial candidate if propitious circumstances arose, irrespective of what the law said. She doubtless secretly hoped that Mary, already in her late thirties and still single, would remain childless, though even if that proved the case, Elizabeth must have realized that claiming the throne after her half-sister might not be as straightforward as she had previously assumed, given the way legal provisions had just been bent and suborned to fit a political-religious agenda as well as being bandied about in the public domain; besides, Mary now stood to throw off the stain of illegitimacy which her co-religionists saw as spurious anyway, whereas for Elizabeth to effect something similar would be well nigh impossible so long as Mary remained on the throne and an uphill struggle thereafter. So, although for the moment Mary's elevation was good news for her too, Elizabeth must have braced herself for a fresh assault on her claim, this one from the Catholics. In combating it, her best bet would be outwardly to conform to the Old religion while tacitly allying herself with her erstwhile betrayers. $^{78}$

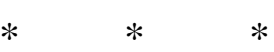

The discursive ferment triggered by the 1553 succession crisis was seemingly short-lived. In Mary's reign, once parliament had annulled Henry VIII's divorce from Katherine of Aragon and rescinded any legislation proclaiming Mary illegitimate (1 Mary, Stat. II, c. 1), there would be little overt discussion of the succession, the queen's underhand attempts to exclude her younger sister coming to naught. Nor did the arrival of Elizabeth, who would never bother to revoke the statute declaring her a bastard, produce 
any elaborate justifications of her right; those only appeared in the wake of the 1570 papal bull of excommunication and were couched in explicitly confessional terms. Meanwhile, the succession debate raged throughout the Elizabethan era despite the statutory embargo, the 1553 coup being repeatedly and loudly condemned by Catholic polemicists, ambiguously treated by Protestant historians such as Grafton and Foxe, and secretly emulated by committed Protestants keen to exclude the Catholic Mary Queen of Scots and also, for a time, her confessionally ambidextrous son James VI of Scotland.

This essay has suggested a new way of seeing the 1553 succession crisis: not merely as an episode in England's political history but also as marking wider changes in political culture. Those changes were uneven in pace and depth, and did not really take off until the restoration of Protestantism under Elizabeth. Even so, as has been argued here, 1553 provided vital inspiration for ideas and modes of political action epitomized by the Elizabethan exclusion crisis. It proved no less crucial to the development of increasingly sophisticated and effective methods of garnering public support.

As Patrick Collinson has shown, the exclusionary measures aimed at Mary Queen of Scots prefigured the analogous bid to stop the accession of Mary's Catholic great-grandson, James Duke of York, in the later seventeenth century. ${ }^{79}$ But neither Collinson nor his successors have traced the genesis of such measures to King Edward's abortive exclusion scheme. So too Peter Lake's longue durée survey of post-Reformation political culture neglects to register the extraordinary mobilization of public opinion in 1553 , characteristically skipping from the Edwardian years to Elizabeth and beyond. ${ }^{80}$ Lake's account elsewhere of the Elizabethan regime's deployment of popular media against popery and its standard-bearer Mary likewise looks forward to the still more expansive uses of agitprop in the following century. ${ }^{81}$ However, as this essay has shown, it is equally important to look back to the 1553 exclusion crisis to appreciate its shaping influence upon the beliefs and actions of Elizabethan Protestants and their Stuart heirs.

So what was the Elizabethan legacy of 1553 ? How did it mould the conduct and mental framework of, say, Cecil and Leicester and also the queen? Cecil had subscribed to the Edwardian letters 
patent, and his subsequent self-justification could not have been more disingenuous. Leicester had lost his father and brother to the block, and his proclamation of Jane at King's Lynn had nearly cost him his life. Determined to protect religion and the state, these men reflected carefully on why Edward's plan had disintegrated, and drew suitable lessons in framing and publicizing the case against the Scottish Mary and devising practical measures that would make it stick.

Any successful attempt to divert the succession, they realized, had to fulfill three conditions. It required a statutory settlement, ideally containing provision for an interregnum; the Protestant political nation ought to be firmly behind it; and it should be enhanced by effective publicity. There is no doubt that the recurrent pleas for Queen-in-Parliament to regulate the order of succession were driven by the memory of Edward's failure to do so; Cecil's plans for a conciliar interregnum $(1563,1584 / 5)$ sought to avoid the sort of shambles that had followed Edward's death. ${ }^{82}$ The Bond of Association (1584), modelled on the Edwardian 'Engagement' as well as on Scottish bands, served to guarantee the loyalty and cooperation of the Protestant governing elites in the event of emergency, and forestall misguided attempts to drum up support for the 'wrong' cause such as those of which Hooper and other Protestants had been guilty back in 1553 . The expert management of oral, scribal, and printed media prepared public opinion and, an added bonus, put pressure on Elizabeth.

For unlike their Edwardian predecessors doing the bidding of their evangelical king, Cecil and his colleagues had to contend with a queen reluctant to address the succession. Elizabeth's refusal either to recognize the Suffolk line (by whom she had nearly been dispossessed of the crown) or to sanction Mary's exclusion surely stemmed from her having been the target of a like device. Nor had she ever forgotten being traduced by evangelicals such as Sandys: 'after my brother's death', she pointedly recalled, 'they openly preached and set forth that my sister and I were bastards'. ${ }^{83}$ While she finally signed Mary Stewart's death warrant, Elizabeth tacitly shielded James's claim with a little exclusionary venture of her own viz. by refusing to legitimate the children of Jane Grey's sister Katherine who were the next in line according to the terms of Henry VIII's will. Paradoxically, the lengthy and intricate 
accession proclamation of James I on 24 March 1603 evinced manifest echoes of the abortive proclamation of Lady Jane Grey half a century earlier. Drafted by Burghley’s son and political heir Sir Robert Cecil, and issued by a body of questionable legitimacy made up of 'the Lords Spirituall and Temporall of this Realme, being here assembled, united, and assisted with those of her late Majesties Privie Counsell, and with great numbers of other principall Gentlemen of quality in the Kingdome, with the Lorde Maior, Aldermen, and Citizens of London, and a multitude of other good Subjects and Commons of this Realme' - note the similarity to the Edwardian 'Engagement' - this earliest Jacobean constitutional document illustrates a comparable attempt to justify a rather dubious royal accession in terms of consent by the majority of the political nation. ${ }^{84}$ But that is already another story.

\footnotetext{
${ }^{1}$ P. Lake and S. Pincus, 'Introduction: Rethinking the Public Sphere in Early Modern England', in The Public Sphere in Early Modern England, ed. Lake and Pincus (Manchester, 2007), p. 6. Despite positing the existence of a post-Reformation
} public sphere, the authors neglect to consider the extraordinary mobilization of public opinion in July 1553.

${ }^{2}$ For a discussion of Henry's policies on the succession, see E. Ives, 'Tudor Dynastic Problems Revisited', Historical Research, 81 (2008), 255-79, at pp. 255-67.

${ }^{3}$ The best account can be found in D. Hoak, 'The Succession Crisis of 1553 and Mary's Rise to Power', in Catholic Renewal and Protestant Resistance in Marian England, ed. E. Evenden and V. Westbrook (Aldershot, 2015), pp. 17-42. I am grateful to Professor Hoak for sharing his work with me in advance of its publication. Also useful are: S. T. Bindoff, 'A Kingdom at Stake, 1553', History Today, 3 (1953), 642-48; R. Tittler and S. L. Batley, 'The Local Community and the Crown in 1553: The Accession of Mary Tudor Revisited', Historical Research, 57 (1984), 131-9; D. Loades, John Dudley, Duke of Northumberland, 1504-1553 (Oxford, 1996), pp. 231ff; D. MacCulloch, Thomas Cranmer: A Life (New Haven and London, 1996), pp. 538-45 and D. MacCulloch, Tudor Church Militant: Edward VI and the Protestant Reformation (London,1999), pp. 39-41; J. Loach, Edward VI (London and New Haven, 2002), pp. 163-79; A. Whitelock and D. MacCulloch, 'Princess Mary's Household and the Succession Crisis, July 1553', Historical Journal, 50 (2007), 265-87; C. Skidmore, Edward VI: The Lost King of England (New York, 2007), pp. 247-83; J. Edwards, Mary I: England's Catholic Queen (New Haven and London, 2011), pp. 76ff. Cf. E. Ives, Lady Jane Grey: A Tudor Mystery (Chichester, 2009). 
${ }^{4}$ See, most recently, Hoak, 'Succession Crisis'; Ives, Lady Jane Grey; Whitelock and MacCulloch, 'Princess Mary’s Household'.

${ }^{5}$ The Council to the sheriff and magistrates of Wiltshire, preserved in the Archives of the Corporation of Tailors, and reproduced in The History of Modern Wiltshire, ed. R. Colt Hoare (6 vols, London, 1822-44), vi: Old and New Sarum or Salisbury, by R. Benson and H. Hatcher, pp. 266-7.

${ }^{6}$ Ives, Lady Jane Grey, p. 147.

7 'Uneasy Lies the Head that Wears a Crown': Dynastic Crises in Tudor and Stuart Britain 1504-1746, The Stenton Lecture 2003 (Reading, 2005), pp. 11-12.

${ }^{8}$ L. Brown, 'Continuity and Change in the Parliamentary Justifications of the Fifteenth-Century Usurpations', in Conflicts, Consequences and the Crown in the Late Middle Ages, ed. L. Clark (Woodbridge, 2007), pp. 157-73; C. Carpenter, 'Resisting and Deposing Kings in England in the Thirteenth, Fourteenth and Fifteenth Centuries', in Murder and Monarchy: Regicide in European History, 1300-1800, ed. R. von Friedeburg (Basingstoke, Macmillan, 2004), pp. 99-121. The dynastic moniker 'Tudor' was rarely if ever used by contemporaries: see C. S. L. Davies, 'Tudor: What's in a Name’, History, 97 (2012), 24-42.

${ }^{9}$ Ives, 'Tudor Dynastic Problems Revisited', pp. 255-67; M. Levine, Tudor Dynastic Problems, 1461-1570 (London, 1973).

${ }^{10}$ Hoak, 'Succession Crisis', p. 23.

${ }^{11}$ Princely Education in Early Modern Britain (Cambridge, 2015), pp. 187-98.

${ }^{12}$ Desiderius Erasmus, The Education of a Christian Prince, ed. \& transl. L. Jardine et al (Cambridge, 1997), p. 6.

${ }^{13}$ Loach, Edward VI, p. 163; Hoak, 'Succession Crisis', p. 23.

${ }^{14}$ The Chronicle of Queen Jane, and of Two Years of Queen Mary, ed. J. G. Nichols (London, 1850), p. 87; Hoak, 'Succession Crisis', p. 23.

${ }^{15}$ While a successfully established female regency of the kind Edward was proposing would be a new departure in England, we should note that Margaret of Anjou had bid for the regency in 1454, some people think Margaret Beaufort briefly played a quasi-regent role in 1509 (though I am not really convinced) and Katherine of Aragon had been regent in Henry's absence abroad in 1513 and Katherine Parr in 1544.

${ }^{16}$ Chronicle of Queen Jane, Appendix I, pp. 89-90.

17 'Uneasy Lies the Head that Wears a Crown', p. 14.

${ }^{18}$ Hoak, 'Succession Crisis', p. 23, suggests that Edward himself may have deleted this section of the 'Devise'. 
${ }^{19}$ Collinson, 'The Monarchical Republic of Queen Elizabeth I', Bulletin of the John Rylands University Library of Manchester, 69 (1987), 394-424; The Monarchical Republic of Early Modern England: Essays in Response to Patrick Collinson, ed. J. F. McDiarmid (Aldershot, 2007); A. Hunt, 'The Monarchical Republic of Mary I', Historical Journal, 52 (2009), 557-72; J. Watts, ““Common Weal” and “Commonwealth”: England's Monarchical Republic in the Making, c.1450c.1530', in The Languages of Political Society, ed. A. Gamberini et al (Rome, 2011), pp. 147-63.

${ }^{20}$ Chronicle of Queen Jane, Appendix I, p. 87.

${ }^{21}$ Chronicle of Queen Jane, Appendix I, p. 87.

${ }^{22}$ Chronicle of Queen Jane, Appendix I, pp. 91-100, at p. 93.

${ }^{23}$ While these terms also applied to Jane's cousin Margaret Clifford, the latter was unaccountably bypassed in favour of her sons, a sign of the unresolved tension between a fondness for individual female relations and an overwhelming antipathy towards female succession.

${ }^{24}$ Pollnitz, Princely Education, pp. 219-28.

${ }^{25}$ As early as 30 May, the Imperial ambassador Jehan Scheyfve was suspicious that Northumberland and his cronies would use 'the excuse of religion' to deprive Mary of the crown, adding that 'As to the said Elizabeth, they are not too particular about her, and reasons for excluding her from the succession might easily be found'; on 4 July, Scheyfve reported that, aside from being declared a bastard, 'The Princess [Mary] has been expressly excluded on religious grounds and because she is asserted to have disobeyed the King and his Council, and infringed the decrees of Parliament'. From: 'Spain: July 1553, 1-10', Calendar of State Papers, Spain, Volume 11: 1553 (1916), pp. 69-80. URL: http://www.british-

history.ac.uk/report.aspx?compid=88483 Date accessed: 15 July 2013. Charles V promptly enquired 'whether the Lady Elizabeth had also been declared a bastard by the will, and if not what pretext had been adopted to debar her from the succession and appoint the eldest daughter of Suffolk', 11 July 1553, The Emperor to his Ambassadors in England, 'Spain: July 1553, 11-15', Calendar of State Papers, Spain, Volume 11: 1553 (1916), pp. 80-90. URL: http://www.britishhistory.ac.uk/report.aspx?compid=88484 [accessed 19 July 2013]. See also an account, likely based on a reliable eye-witness report, of how Edward justified his plan to the Council, lawyers, and others, in 'The Vita Mariae Angliae Reginae of Robert Wingfield of Brantham’, ed. D. MacCulloch, Camden Miscellany, 28 (1984), 181-301, at pp. 246-7.

${ }^{26}$ Henry's will stipulated that upon the demise of the Suffolk line the succession should devolve to 'the next rightfull heyres' i.e. the descendants of his elder sister Margaret. For text of the will, see T. B. Howell, A Complete Collection of State Trials, 21 vols (London, 1816), i. 743-53 (quotation p. 748); for discussions of its provisions, see E. Ives, 'The Will of Henry VIII: A Forensic Conundrum', Historical Journal, 35 (1992), 779-804, and E. Ives, 'Henry VIII's Will: The Protectorate 
Provisions of 1546-7', Historical Journal, 37 (1994), 901-14; R. A. Houlbrooke, 'Henry VIII's Wills: A Comment', Historical Journal, 37 (1994), 891-9.

${ }^{27}$ See S. Doran and P. Kewes, 'The Earlier Elizabethan Succession Question Revisited', in Doubtful and Dangerous: The Question of Succession in Late Elizabethan England, ed. S. Doran and P. Kewes (Manchester, 2014), pp. 20-44.

${ }^{28}$ Howell, A Complete Collection of State Trials, i. 747.

${ }^{29}$ Henry presumably believed that the act of supremacy was sufficient unto the purpose and saw no compelling reason to broach religion in the regulations pertaining to the succession; the 1544 Act did nevertheless re-impose the oath requiring abjuration of papal authority. Ives has argued that Henry's packing of his son's future Council with committed reformers and his corresponding exclusion of conservatives was a sign that the king wished for the reforms to be carried forward during Edward's minority rule ('Henry VIII's Will'); this argument has been refuted by Houlbrooke ('Henry VIII's Wills').

${ }^{30}$ Chronicle of Queen Jane, Appendix I, p. 101.

${ }^{31}$ According to Wingfield, Edward was particularly scathing of Elizabeth's mother: 'it was the fate of Elizabeth, my other sister, to have Anne Boleyn for a mother; this woman was indeed not only cast off by my father because she was more inclined to couple with a number of courtiers rather than reverencing her husband, so mighty a king, but also paid the penalty with her head - a greater proof of her guilt' ('Vita Mariae', p. 247).

${ }^{32}$ Hoak, 'Succession Crisis', p. 30.

${ }^{33}$ See M. Levine, Tudor Dynastic Problems, 1460-1571 (London, 1973), pp. 83-4; Loades, John Dudley, pp. 240-1; Hoak, 'Succession Crisis', pp. 18, 33-4; H. Nenner, The Right to be King: The Succession to the Crown of England, 1603-1714 (Basingstoke, 1995), pp. 4, 44, 57, 21.

${ }^{34}$ Jane Grey, p. 166; and his ‘Tudor Dynastic Problems Revisited’, pp. 267-72.

${ }^{35}$ To put it differently, if Henry's statutory regulations violated the common law rule against bastard inheritance, Edward's letters patent, and any statute to which they might give rise, violated the common law rule of primogeniture in giving the crown to the daughter rather than the mother from whom her title derived.

${ }^{36} 28$ Hen. VIII, c. 7, clause xviii.

${ }^{37}$ MacCulloch, Thomas Cranmer, pp. 539-41; Hoak, 'Succession Crisis', p. 35. Understandably, Cranmer would later deny being party to any deal with Northumberland in a letter sent to Queen Mary during his imprisonment. See Certain most godly, fruitful, and comfortable letters of such true Saintes and holy Martyrs of God, as in the late bloodye persecution here within this Realme, gaue their lyues for the defence of Christes holy gospel written in the tyme of their affliction and cruell imprysonment, ed. M. Coverdale (London, 1564), p. 3. 
${ }^{38}$ Chronicle of Queen Jane, Appendix I, pp. 90-1, at p. 90. The volume reproduces the names of all the signatories. Given how many of those embroiled in the 1553 coup would rise to prominence under Elizabeth - chief among them William Cecil, later Lord Burghley and Robert Dudley, later Earl of Leicester - it is startling that there is no sustained account of how the experience of that fiasco shaped the exclusionary measures they sought to unleash against the dreaded popish successor, Mary Queen of Scots. For the text of the Bond of Association, which in contemporary manuscripts is called either the 'Association' or 'The Instrument of Association', see 'Lincolnes Inne “Association for the defence of Queen Elizabeth”” printed in The Egerton Papers, ed. J. P. Collier, Camden Society, 12 (840), pp. 108-11. For discussion of the Bond's significance, see D. Cressy, 'Binding the Nation: The Bonds of Association, 1584 and 1696', in Tudor Rule and Revolution: Essays for G. R. Elton from his American Friends, ed. D. J. Guth and J. W. McKenna (Cambridge, 1982), pp. 217-34; P. Collinson, 'The Elizabethan Exclusion Crisis and the Elizabethan Polity', Proceedings of the British Academy, 84 (1993), 5192, recently reprinted in P. Collinson, This England: Essays on the English Nation and Commonwealth in the Sixteenth Century (Manchester, 2011), pp. 61-97.

${ }^{39}$ Hoak, 'Succession Crisis', p. 19; Ives, Lady Jane Grey, pp. 165-6. Again, the names of subscribers are given in Chronicle of Queen Jane, Appendix I: pp. 99-100. The garnering of subscriptions to the Engagement might be fruitfully compared to the much bigger signature campaign for the Oath of Succession of 1534; had they won, Jane's supporters might well have tried to launch one too.

${ }^{40}$ Chronicle of Queen Jane, p. 2; The Diary of Henry Machyn: Citizen and Merchant-taylor of London, from A.D. 1550 to A.D. 1563, ed. J. G. Nichols (London, 1848), p. 35; Richard Hilles to Heinrich Bullinger, 9-10 July 1553, in Original Letters Relative to the English Reformation: Written during the Reigns of King Henry VIII, King Edward VI and Queen Mary, Chiefly from the Archives of Zurich, ed. H. Robinson (Cambridge, 1846), i. 272-5. Hilles was among the few elated by the news, and certainly did not baulk at the exclusion of both of the king's sisters, '(of whom the elder, Mary, is ill-disposed to the pure doctrine of the gospel)' (p. 273).

${ }^{41}$ Jane, by the Grace of God Quene of England... (London, 1553); Chronicle of the Grey Friars of London, ed. J. G. Nichols (London, 1852), pp. 78-9. Sent two days before Jane's proclamation, the Council's missive to the chief Surrey officials must have struck the addressees as distinctly odd, because, pretending that the king was still alive, the Councillors accused Mary of wishing to resist Edward's plans for the succession which were still under wraps! 'To our loving frendes the Deputies of the Kinges Majestie's Lieutenantes in the County of Surrey, and to the Shirif, the Chief Justices and others the worshipfulls of the same County', 8 July 1553, in J. More Molyneux, 'Letters Illustrating the Reign of Queen Jane', Archaeological Journal, 30 (1873), 273-8, at 276. 
${ }^{42}$ Jane, by the Grace of God Quene of England.

${ }^{43}$ Jane, by the Grace of God Quene of England.

${ }^{44}$ Circular letter to the lieutenants of counties, announcing the accession of the Lady Jane to the crown (MS. Lansdowne 3) in the writing of Northumberland art 24, in Chronicle of Queen Jane, Appendix I, pp. 103-5: this bears Cecil's endorsement 12 July 1553 but seems to have been produced earlier.

${ }^{45}$ Wriothesley, A Chronicle of England during the Reigns of the Tudors, from A.D. 1485 to 1559, ed. W. D. Hamilton, 2 vols, Camden Society, new series, 11, 20 (1875-77), ii: 88; Two London Chronicles from the Collections of John Stow, ed. C. L. Kingsford, Camden Miscellany, xii (1910), pp. 26-7. Ridley seems to have tried to prepare the ground earlier. He may have persuaded John Hodgkins, suffragan bishop of Bedford, to suppress the customary prayer for Mary and Elizabeth in the sermon the latter had preached on 2 July, that is, four days before King Edward's death, and in his own sermon of 9 July, the eve of Jane's proclamation, 'callyd bothe the sayd ladys bastarddes, that alle the peopull was sore anoyd with hys worddes'. See Chronicle of the Grey Friars, p. 78.

${ }^{46}$ J. Foxe, Acts and Monuments (4th edn., London, 1583), pp. 2110-11; C. Law, 'Religious Change in the University of Cambridge, c. 1547-84', unpublished PhD thesis (University of Cambridge, 2013), pp. 66-7

${ }^{47}$ An apologye made by the reuerende father and constante martyr of Christe Iohn Hooper late bishop of Gloceter and Worceter againste the vntrue and sclaunderous report that he should be a maintainer and encorager of suche as cursed the Quenes highnes that then was, Quene Marye (London, 1562), sig. A8v; D. G. Newcombe, ODNB article on Hooper. ${ }^{48}$ The copie of a pistel or letter sent to Gilbard Potter in the tyme When he was in prison, for speaking on our most true queens part the Lady mary before he had his eares cut of. The .xiij. of Julye (London, 1 Aug. 1553); Machyn, Diary, pp. 356.

${ }^{49}$ Whitelock and MacCulloch, 'Princess Mary’s Household', p. 285.

50 'To oure lovyng frends the Sheriff of Nottingham and Derbyshire, and to the Justices of peace of the said counties and to every of them', in The Retrospective Review, $2^{\text {nd }}$ series, 1 (1827), 504-5. The date given here is 12 July but this must be a mis-transcription for 14 July ('xii' instead of 'xiv'), for the letter states that Northumberland, who would not leave London till the 13th, was already in the field.

${ }^{51}$ The Council to the sheriff and magistrates of Wiltshire, pp. 266-7. By 18 July, they reverted back to harping on the 'rebellion of the base multitude', but this time they refrained from naming Mary as the instigator or citing any religious motives: see Queen Jane to certain gentlemen, to repair into Buckinghamshire, to quell the disturbances there: To our trusty 
and welbeloved Sir John St. Lowe and Sir Anthony Kingstone, knts., 18 July 1553 , in J. Strype, Ecclesiastical Memorials (3 vols in 6 parts, Oxford, 1822), iii, pt. ii, pp. 172-3, at p. 173.

52 The Literary Remains of Lady Jane Grey, ed. N. Harris Nicolas (London, 1825), pp. liv-lvii, at p. lvi.

${ }^{53}$ Hughes and Larkin (eds), Tudor Royal Proclamations, II: 3; Marie by the grace of God, Quene of Englande, Fraunce, and Irelande, defendour of the faith, and in the earth supreme hed [sic] of the Churches of Engläd and Irelande (London, 19 July 1553): the authorship of the proclamation has not been taken on board in modern studies which typically credit it to Mary: see, inter alia, Ives, 'Tudor Dynastic Problems Revisited', p. 272; Hunt, ‘The Monarchical Republic of Mary I’, pp. 560-1. Revealingly, Machyn noted that Mary was 'syster of the late kyng Edward the vi. and doythur unto the nobyll kyng Henry the viii', even though the proclamation only mentioned the former: see Diary, p. 37.

${ }^{54}$ Hoare (ed.), History of Modern Wiltshire, vi, p. 267.

${ }^{55}$ In probing the Council's defection to Mary, scholars characteristically rely on a much later and heavily doctored account of Arundel's supposed speech to his runaway colleagues at Baynard's Castle which has the Earl assert that 'by righte of succession this Crowne discends uppon Mary lawfull daughter to Kinge Henry the Eighte' (J. G. Nichols, 'Life of the last Fitz-Alan, Earl of Arundel', Gentleman's Magazine, 1st ser., 103/2 (1833), 11-18, 118-24, 209-15, 490-500 at 119). See e.g. Hunt, 'Monarchical Republic of Mary I', p. 561.

${ }^{56}$ Wriothesley, Chronicle, pp. 88-9; cf. Chronicle of the Grey Friars, p. 80; 'Events of the Kingdom of England Beginning with King Edward VI until the Wedding of the Most Serene Prince Philip of Spain and the Most Serene Queen Mary as Related by Monsignor G. F. Commendone'0), printed in The Accession, Coronation and Marriage of Mary Tudor as Related in Four Manuscripts of the Escorial, tr. C. V. Malfatti (Barcelona, 1956), p. 20.

${ }^{57}$ Ives, 'Tudor Dynastic Problems Revisited', p. 271.

${ }^{58}$ Wingfield, 'Vita Mariae', p. 251; 'A Letter of the Lady Mary, sent to the Lords of the Counsell, wherin she claymeth the crowne after the deceasse of Kyng Edward', in J. Foxe, Acts and Monuments ( $2^{\text {nd }}$ edn., London, 1570), pp. 1605-6: copies were simultaneously sent to the localities (on its reception in Great Yarmouth see Tittler and Battley, 'Accession', p. 136); Mary to Sir Edward Hastings, in Strype, Ecclesiastical Memorials, iii, pt. ii, pp. 171-2. Similar letters went to various other recipients: A. Bryson, 'The speciall men in every shere: The Edwardian Regime, 1547-1553' (Ph.D. thesis, St Andrews, 2001), p. 285. The letter to the Council also cited 'other circumstaunces aduauncing our right' (Foxe, p. 1605); that to Hastings - the agency of 'God's providence' (Strype, p. 171). For the Council's impudent reply insisting that in consequence of Henry's lawful repudiation of the Aragon marriage, Mary had been 'iustly made illegitimate and vnheritable to the crowne 
Imperial of this Realme', see Foxe, Acts (1570), p. 1606. Although Elizabeth is nowhere named, much of the argument aimed at her elder half-sister would have by default applied to her as well.

${ }^{59}$ Proclamation of 18 July 1553, quoted and discussed in L. Porter, Mary Tudor: The First Queen (London, 2007), pp. 20810; Acts of the Privy Council of England, ed. J. R. Dasent (46 vols, London, 1890-1964), iv. 296.

${ }^{60}$ The Ambassadors in England to the Emperor, 12 July 1553, 'Spain: July 1553, 11-15', Calendar of State Papers, Spain, Volume 11: 1553 (1916), pp. 80-90. URL: http://www.british-history.ac.uk/report.aspx?compid=88484 [accessed 19 July 2013]; E. Harris Harbison, Rival Ambassadors at the Court of Queen Mary (Princeton, 1940), pp. 49-50.

${ }^{61}$ Sir Philip Hoby and Sir Richard Moryson, Commissioners at Brussels, to the Council, 15 July 1553, in Nicolas, Literary Remains, pp. lxiii-xv; Harbison, Rival Ambassadors, p. 47.

${ }^{62}$ J. Loach has argued that Northumberland was prepared to surrender English territory, including Calais, to secure French backing for Jane, see J. Loach, ““A close league with the king of France”: Lady Jane Grey’s Proclamation in French and its Part in a Planned Betrayal', Proceedings of the Huguenot Society of Great Britain and Ireland, 25 (1991), 234-43. Ives contests this view in his Lady Jane Grey, pp. 196-7. The evidence is inconclusive.

${ }^{63}$ P. Kewes, 'The Exclusion Crisis of 1553 and the Elizabethan Succession', in Mary Tudor: Old and New Perspectives, ed. S. Doran and T. S. Freeman (Basingstoke, 2011), pp. 49-61.

${ }^{64}$ Cranmer, p. 543.

${ }^{65}$ Letter addressed by Wyatt and other adherents of Mary to their county neighbours; these men also planned to send a similar appeal to the Privy Councillors. See Bryson, 'The speciall men in every shere', p. 280.

${ }^{66}$ Tittler and Battley, 'Accession'.

${ }^{67}$ Juan Martinez de Recalde to Francisco de Ledesma. Bilbao, 1 August, 1553. 'Spain: August 1553, 1-5', Calendar of State Papers, Spain, Volume 11: 1553 (1916), pp. 127-150. URL: http://www.british-history.ac.uk/report.aspx?compid=88487 [accessed 05 August 2013].

68 'Spain: August 1553, 1-5', Calendar of State Papers, Spain, Volume 11: 1553 (1916), pp. 127-150. URL: http://www.british-history.ac.uk/report [accessed 07 August 2013].

${ }^{69}$ From: 'Spain: September 1553, 16-20', Calendar of State Papers, Spain, Volume 11: 1553 (1916), pp. 238-250. URL: http://www.british-history.ac.uk/report.aspx?compid=88495 Date accessed: 10 August 2013.

${ }^{70}$ This had to do with the conception of the crown as a corporation, forcefully articulated in the next reign by the famous common lawyer Edmund Plowden.

${ }^{71}$ The Statutes of the Realm, 11 vols (London, 1810-28), ii. 499. 
72 Tittler and Battley, 'Accession'; Bryson, 'The speciall men in every shere', pp. 271-89; Whitelock and MacCulloch, 'Princess Mary's Household'. It is difficult to agree with J. Loach, Parliament and the Crown in the Reign of Mary Tudor (Oxford, 1986), that the accession was basically a vote for Catholicism.

${ }^{73}$ On the key role of Mary's Catholic household and following, see Whitelock and MacCulloch, 'Princess Mary's Household'.

${ }^{74}$ Kewes, 'Exclusion Crisis’, p. 50.

${ }^{75}$ See, inter alia, Wingfield's 'Vita Mariae', pp. 245-50. The earliest cue had been furnished by Mary’s $18^{\text {th }}$ July proclamation: see Porter, Mary Tudor, p. 209.

${ }^{76}$ See R. Beeard, A godly psalm, of Mary Queen, which brought us comfort all, through God, whom we of duty praise, that gives her foes a fall (London, 1553). Other Protestant works hailing Mary's accession include Narratio historica vicissitudinis rerum ([Wittenberg,] 1553) translated into English as Historical narration of certain events that took place in the kingdom of Great Britain in the month of July, in the year of our Lord 1553, transl. J. B. Inglis, ed. J. Ph. Berjeau (London, 1865); and R. Taverner, An Oration gratulatory made upon the joyfull proclaiming of the moste noble Princes Quene Mary Quene of Englande (London, 1553).

${ }^{77}$ The saying of Iohn late Duke of Northumberlande uppon the scaffolde, at the tyme of his execution. The. xxii. of Auguste (London, 1553); W. K. Jordan and M. R. Gleason, The saying of John Late Duke of Northumberland Upon the Scaffold, 1553 (Cambridge, Mass., 1975), reprinted from the Harvard Library Bulletin, 23 (1975).

${ }^{78}$ D. Starkey, Elizabeth: The Struggle for the Throne (New York, 2001).

79 'The Elizabethan Exclusion Crisis and the Elizabethan Polity', Proceedings of the British Academy, 84 (1994), 51-92.

80 'Post-Reformation Politics, or on Not Looking for the Long-Term Causes of the English Civil War', in The Oxford Handbook of the English Revolution, ed. M. J. Braddick (Oxford, 2015), pp. 21-39.

${ }^{81}$ Bad Queen Bess? Libels, Secret Histories, and the Politics of Publicity in the Reign of Queen Elizabeth I (Oxford, 2016). In this book Lake revamps his terminology, commenting on his abandonment of the infelicitous 'public sphere': see p. 468. ${ }^{82}$ For further discussion, see P. Kewes, 'Parliament and the Succession in Elizabethan England', in Writing the History of Parliament, ed. P. Cavill and A. Gajda (Manchester, 2017), 000-000, and This Great Matter of Succession: Drama, History, and Elizabethan Politics (Oxford, 2017).

${ }^{83}$ Elizabeth's speech, 1566, in Elizabeth I: Collected Works, ed. L. Marcus et al (Chicago, 2000), p. 97.

${ }^{84}$ Stuart Royal Proclamations, ed. J. F. Larkin and P. L. Hughes (2 vols, Oxford, 1973), i. 1-4, at p. 2. On the genesis of the proclamation, see A. Courtney, 'The Accession of James VI to the English Throne, 1601-1603', unpublished M. Phil. thesis 
(University of Cambridge, 2004), which supersedes L. L. Peck, 'Kingship, Counsel and Law in Early Stuart Britain', in The Varieties of British Political Thought, 1500-1800, ed. J. G. A. Pocock with the assistance of G. J. Schochet and L. G. Schwoerer (Cambridge, 1993), pp. 80-115. The Jacobean succession violated the terms of Henry VIII's will. For an account of the reception of James's proclamation, and the acute ambiguity surrounding the new king's title apparent in the myriad competing constructions of his claim in the flurry of print that greeted his accession, see P. Kewes, 'Hamlet and Politics', The Review of Politics, 78: 3 (2016), 000-000; see also the Stuart Successions database at http://stuarts.exeter.ac.uk/database/ and Literature of the Stuart Successions, ed. P. Kewes and A. McRae (Oxford, 2017). 